\title{
Application of the composite maps method for landslide susceptibility assessment and its potential use for other natural risk analyses
}

\author{
Sergio A. Sepúlveda ${ }^{12}$ sesepulv@ing.uchile.cl, Jacobus P. Le Roux ${ }^{12}$, Gisella Palma ${ }^{1}$
}

\begin{abstract}
Composite maps have previously been applied to paleogeographic reconstructions and as an aid to mineral exploration. However, because they can combine different criteria that are used in risk and feasibility assessment into a single map with equal or weighted input from all the parameters, decisionmaking can be optimized. The methodology is particularly suitable for the evaluation of landslide hazard and susceptibility assessment, as it can combine the unfavourable factors typically associated with mountainous terrains. Composite maps also have the potential to standardize prediction and prevention criteria for different areas. The methodology is described together with an hypothetical example and a real case study in Patagonia, the results of which are compared with a susceptibility analysis of the same area using stochastic methods.
\end{abstract}

Keywords: Geological hazards; slope failure, landslide susceptibility.

\section{RESUMEN}

Los mapas compuestos han sido aplicados previamente en reconstrucciones paleogeográficas y como apoyo a la exploración minera. Sin embargo, dado que pueden combinar en un solo mapa diferentes criterios que usualmente se utilizan en análisis de riesgo y factibilidad, otorgando igual o distinto peso a los distintos parámetros, la toma de decisiones se ve optimizada. La metodología es particularmente aplicable en la evaluación de susceptibilidad y amenaza de remociones en masa, ya que puede combinar factores desfavorables típicamente presentes en terrenos montañosos. Los mapas compuestos tienen el potencial de estandarizar las predicciones y criterios preventivos para distintas áreas. Esta metodología se describe en conjunto con un ejemplo teórico y un estudio de caso real en la Patagonia, cuyos resultados son comparados con análisis de susceptibilidad en la misma zona usando métodos estocásticos.

Palabras clave: Amenaza Geológica; falla en las laderas; susceptibilidad a deslizamientos de tierra.

Recibido el 22 de julio de 2013, aceptado el 2 de diciembre de 2013.

\footnotetext{
1 Departamento de Geología, Facultad de Ciencias Físicas y Matemáticas, Universidad de Chile, Plaza Ercilla 803, Santiago, Chile.

2 Centro de Excelencia en Geotermia de los Andes.
} 


\section{INTRODUCTION}

Risk assessment is an important component of the decision-making process in project evaluations as well as urban and territorial planning. It involves different steps such as susceptibility, hazard and vulnerability evaluation of risks. The evaluation criteria have to be weighed against one another, which may not be an easy task because of the wide variety of very different factors that can be involved. Such decisions are of particular importance where human lives and/or property are at stake. In the case of risk assessment, factors that pose a threat are often quantified, plotted and contoured on susceptibility, hazard or risk maps, where unsafe areas can be identified in order to take preventative action. However, if different maps produce conflicting results, more areas may be excluded from human occupation or restricted to other activities than may be really necessary. In an age of increasing population growth and decreasing natural resources, it is therefore imperative that such maps be optimized to highlight only those areas that really pose a significant threat. During the last two decades, a number of methods using index parameter or factor maps that can be weighted and combined in a spreadsheet or GIS have been developed for natural hazard and risk assessment (e.g. NADIM et al. 2006; ALEOTTI \& CHOWDHURY 1999; LARA \& SEPÚLVEDA 2010; KAMP et al. 2008). They usually have an important degree of subjectivity in the selection of parameters, the applied weights and the way the data are assigned to the terrain. Here we discuss a more objective method that can combine any number of different kinds of maps into a single, composite map, where each factor provides an equal input into the final product.

The basic method was originally designed to assist in uranium exploration by combining different criteria considered to be favourable for mineralization (LE ROUX 1982), and has also been used for paleogeographic reconstructions (LE ROUX \& RUST 1989; LE ROUX 1997). However, the methodology is ideally suited to the type of problem outlined above. It has the advantage that the assignation of numeric results to the terrain is completely objective and not only designed for a specific hazard. In this paper, we provide examples of the application of this methodology to the evaluation and combination of terrain factors used for landslide susceptibility assessment and discuss its potential use for analysis of other geohazards.

\section{MATERIALS AND METHODS}

Composite maps have the advantage that any number of different types of information can be combined into a single map, as long as such information can be quantified. This is effected by normalizing the different kinds of data in such a way that each data type has the same range of values for the area to be investigated, allowing the values to be added so that equal input is obtained from the different parameters. For example, if slope gradients in an area vary from 0.01 to 0.2 , and the percentage of clay in the soil from 20 to $100 \%$, simply adding the values would practically lose all the input of the slope gradient because of its much lower values, even though it might be a greater susceptibility factor than the clay content. However, after normalizing, both parameters would have the same range of dimensionless values and thus provide equal input to the composite map.

The methodology is illustrated with an hypothetical example (Table 1 and figure 1) of assessing the optimum site for a geothermal power plant, based on a susceptibility analysis of a simple shallow soil slide.

The first step in constructing a composite map is to decide on the number of base maps or parameters for which sufficient data are available and which would provide 
relevant information in the risk or feasibility assessment process. For instance, if 5 base maps or parameters are used, each should be allotted a $5 / 100^{\text {th }}$ or $20 \%$ share in the composite map, i.e. all 5 parameters must have a range between 0 and 20. In our example (Fig. 1), we will consider 3 base maps in a mountainous terrain in which it is planned to build a geothermal power plant installation. Figure 1a depicts the topography and shows the location of an alluvial fan, with higher slopes indicated by a closer spacing of the elevation contours. These areas would be considered to pose a greater threat for slope failure than areas with a lower slope. The numbers in figure $1 \mathrm{~b}$ are data stations on an arbitrary grid, which are used in all three base maps. Base map 1 (Fig. 1c) is derived from the elevation contours in figure $1 \mathrm{a}$, in which the slope gradients are indicated at the different data stations of figure $1 \mathrm{~b}$. Base map 2 (Fig. 1d) portrays isopachs contouring the soil thickness above solid bedrock, as obtained from outcrops and boreholes. A thicker soil profile is regarded to present a greater susceptibility in this case. Finally, base map 3 (Fig. 1e) shows the percentage of vegetation cover, in which a higher vegetation density is considered to diminish the risk of slope failure. For the purpose of this exercise, an equal weight is given to the three parameters.
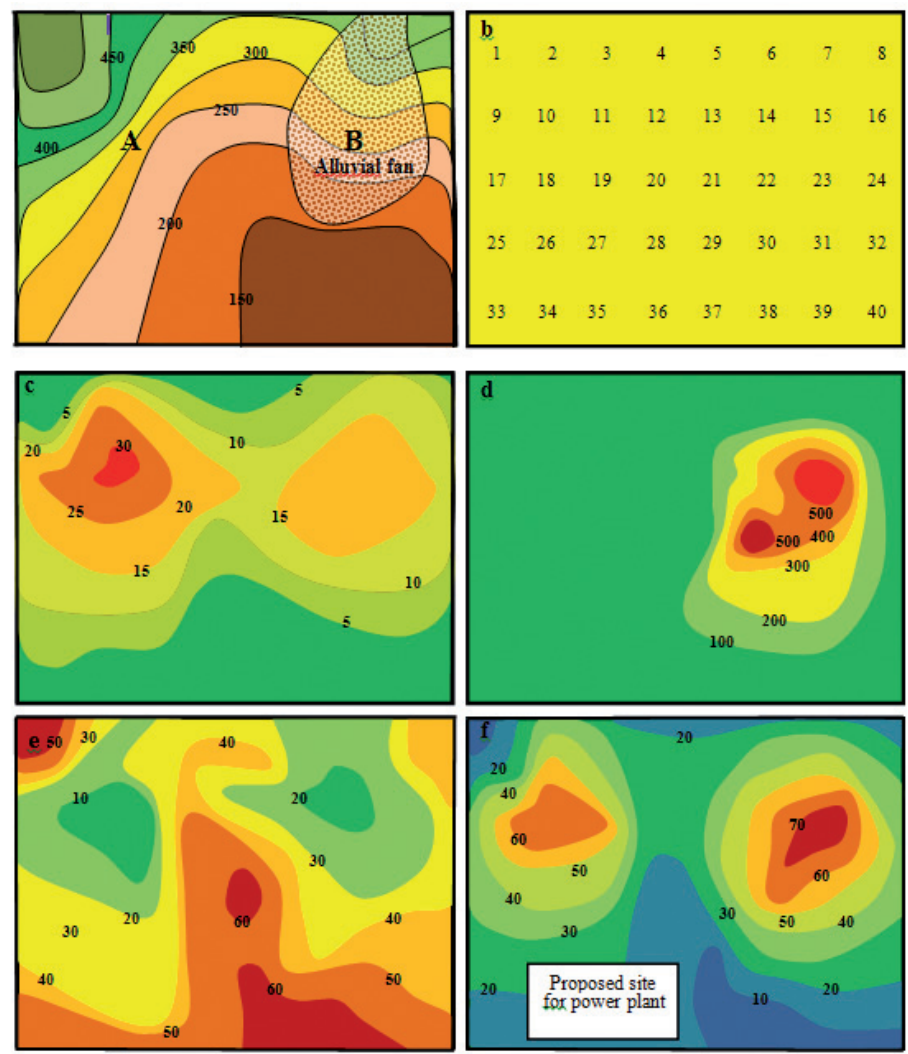

Fig. 1. Base maps and composite map of hypothetical case study. a) Topography of study area showing areas of interest (A and B). Elevation contours in $m$ a.s.l.; b) Distribution of data stations; c) Contoured slope gradient in degrees; d) Contoured soil thickness in centimeters; e) Contoured vegetation cover in percentage; f) Composite map with dimensionless values. High-risk zones where catastrophic soil slope failure may take place are shaded in brownish red and dark red. 
Ideally, all base maps should share the same data stations (Fig. 1b). However, if this is not possible, the data on each map should be contoured first and arbitrary stations laid out on a grid, of which the locations should coincide on all base maps. The parameter value for each station should then be determined by intra- or extrapolation, which must be done for all stations on all base maps.

The next step is to set up a table, preferably using a spreadsheet such as Excel to speed up calculations (LE ROUX 1991). An example is provided in Table 1. In the first column the station numbers are entered, followed in the second column by the real or interpolated raw data for each station on the first base map. A conversion factor $C$ is then calculated (see last row in Table 1), given by the percentage value $P$ (33.33 in this case), divided by the range of original values on this base map. Therefore,

$$
C=P /\left(S_{h}-S_{l}\right)
$$

where $S_{h}$ and $S_{l}$ are the highest and lowest values, respectively, in column 2 . In column 3 , the normalized value for each station is calculated by $C\left(S_{i}-S_{l}\right)$, where $S_{i}$ is the particular station value. The same procedure is repeated for the other base maps.

Table 1. Example of Calculation of Parameters for composite map. Results are ILLUSTRATED IN Figure 1

\begin{tabular}{|c|c|c|c|c|c|c|c|}
\hline $\begin{array}{l}\text { Station } \\
\text { No. }\end{array}$ & $\begin{array}{c}\text { Slope } \\
\text { (degrees) }\end{array}$ & $\begin{array}{l}\text { Slope } \\
\text { Factor }\end{array}$ & $\begin{array}{l}\text { Soil thickness } \\
(\mathrm{cm})\end{array}$ & $\begin{array}{l}\text { Thickness } \\
\text { Factor }\end{array}$ & $\begin{array}{l}\text { Vegetation } \\
\text { cover (\%) }\end{array}$ & $\begin{array}{l}\text { Vegetation } \\
\text { factor }\end{array}$ & Composite \\
\hline 1 & 3 & 2,02 & 40 & 2,16 & 50 & 8,06 & 12 \\
\hline 2 & 28 & 27,27 & 17 & 0,82 & 13 & 27,95 & 56 \\
\hline 3 & 15 & 14,14 & 23 & 1,17 & 35 & 16,13 & 31 \\
\hline 4 & 8 & 7,07 & 27 & 1,40 & 40 & 13,44 & 22 \\
\hline 5 & 6 & 5,05 & 33 & 1,75 & 43 & 11,83 & 19 \\
\hline 6 & 10 & 9,09 & 47 & 2,57 & 21 & 23,65 & 35 \\
\hline 7 & 15 & 14,14 & 99 & 5,60 & 27 & 20,43 & 40 \\
\hline 8 & 13 & 12,12 & 52 & 2,86 & 46 & 10,21 & 25 \\
\hline 9 & 26 & 25,25 & 23 & 1,17 & 12 & 28,49 & 55 \\
\hline 10 & 34 & 33,33 & 4 & 0,06 & 5 & 32,25 & 66 \\
\hline 11 & 30 & 29,29 & 3 & - & 3 & 33,33 & 63 \\
\hline 12 & 16 & 15,15 & 23 & 1,17 & 51 & 7,53 & 24 \\
\hline 13 & 14 & 13,13 & 42 & 2,27 & 39 & 13,98 & 29 \\
\hline 14 & 17 & 16,16 & 371 & 21,45 & 23 & 22,58 & 60 \\
\hline 15 & 19 & 18,18 & 528 & 30,61 & 20 & 24,19 & 73 \\
\hline 16 & 15 & 14,14 & 104 & 5,89 & 29 & 19,35 & 39 \\
\hline 17 & 15 & 14,14 & 34 & 1,81 & 26 & 20,97 & 37 \\
\hline 18 & 21 & 20,20 & 7 & 0,23 & 17 & 25,80 & 46 \\
\hline 19 & 18 & 17,17 & 11 & 0,47 & 11 & 29,03 & 47 \\
\hline 20 & 7 & 6,06 & 38 & 2,04 & 57 & 4,30 & 12 \\
\hline 21 & 11 & 10,10 & 87 & 4,90 & 60 & 2,69 & 18 \\
\hline 22 & 16 & 15,15 & 575 & 33,35 & 36 & 15,59 & 64 \\
\hline 23 & 15 & 14,14 & 329 & 19,01 & 29 & 19,35 & 52 \\
\hline 24 & 14 & 13,13 & 201 & 11,54 & 36 & 15,59 & 40 \\
\hline 25 & 8 & 7,07 & 43 & 2,33 & 35 & 16,13 & 26 \\
\hline 26 & 9 & 8,08 & 32 & 1,69 & 36 & 15,59 & 25 \\
\hline 27 & 10 & 9,09 & 44 & 2,39 & 36 & 15,59 & 27 \\
\hline 28 & 4 & 3,03 & 49 & 2,68 & 53 & 6,45 & 12 \\
\hline 29 & 8 & 7,07 & 115 & 6,53 & 40 & 13,44 & 27 \\
\hline 30 & 5 & 4,04 & 219 & 12,59 & 63 & 1,07 & 18 \\
\hline 31 & 7 & 6,06 & 231 & 13,29 & 48 & 9,14 & 28 \\
\hline 32 & 6 & 5,05 & 94 & 5,31 & 43 & 11,83 & 22 \\
\hline
\end{tabular}




\begin{tabular}{|c|c|c|c|c|c|c|c|}
\hline $\begin{array}{c}\text { Station } \\
\text { No. }\end{array}$ & $\begin{array}{c}\text { Slope } \\
\text { (degrees) }\end{array}$ & $\begin{array}{c}\text { Slope } \\
\text { Factor }\end{array}$ & $\begin{array}{c}\text { Soil thickness } \\
(\mathrm{cm})\end{array}$ & $\begin{array}{c}\text { Thickness } \\
\text { Factor }\end{array}$ & $\begin{array}{c}\text { Vegetation } \\
\text { cover (\%) }\end{array}$ & $\begin{array}{c}\text { Vegetation } \\
\text { factor }\end{array}$ & Composite \\
\hline 33 & 5 & 4,04 & 54 & 2,97 & 57 & 4,30 & 11 \\
\hline 34 & 4 & 3,03 & 57 & 3,15 & 49 & 8,60 & 15 \\
\hline 35 & 3 & 2,02 & 61 & 3,38 & 38 & 14,51 & 20 \\
\hline 36 & 1 & 0,00 & 62 & 3,44 & 51 & 7,53 & 11 \\
\hline 37 & 1 & 0,00 & 73 & 4,08 & 62 & 1,61 & 6 \\
\hline 38 & 1 & 0,00 & 75 & 4,20 & 65 & $-0,00$ & 4 \\
\hline 39 & 1 & 0,00 & 73 & 4,08 & 58 & 3,76 & 8 \\
\hline 40 & 2 & 1,01 & 67 & 3,73 & 53 & 6,45 & 11 \\
\hline$C$ & 1,01 & & 0,0583 & & 0,5376 & & \\
\hline
\end{tabular}

Before adding the values for each station, two additional calculations may be required. The first is used where any particular data station on any one (or more) of the base maps does not contain reliable information, for whatever reason. In order not to lose the input from this station, in which the sum value would be diluted by the lack of data on one or more of the maps, the reliable values from the other maps for this station are added and multiplied by $I / R$, where $I$ is the total number of maps or parameters considered for the area and $R$ is the number of maps with reliable input values.

For the second correction it is important that the significance of all the parameters be fully understood in terms of their risk or favourability factors. If a high slope gradient is considered to present greater susceptibility to catastrophic slope failure than a low slope gradient, the normalized values should be used as they were calculated in column 3 . However, if a high percentage of vegetation cover is considered to pose a lower risk for slope failure than sparse vegetation, the normalized values should be inverted before adding them to the other map values. Inversion is done by simply subtracting the normalized value from $S_{h}$ for each station, i.e., if $S_{h}$ is 20 , an original value of 15 would become 5 and a value of 3 would become 17 . In our example, this inversion applies for the Vegetation column in Table 1.

Finally, all the normalized or inverted values are added for each station (column Composite in Table 1), the sums are entered at the respective station locations, and contours are drawn to comprise the composite map (Fig. 1f).

If certain factors are considered to be more important than others, the different parameters can also be weighted, but this should be done only after normalization and inversion. Furthermore, this would require detailed knowledge of each risk factor and would also introduce some bias, depending on the criteria and judgement of the researcher(s). If we examine the base maps in figure 1 , two zones of interest can be defined, marked as A and B on figurela. Zone A is shown by base map 1 (Fig. 1c) to have the highest slope in the study area and would thus be considered to represent a high-susceptibility zone. This is supported by base map 3 (Fig. 1e), which shows a low vegetation density. However, base map 2 (Fig. 1d) indicates that this zone has very little topsoil, which decreases the risk of large-scale soil slope failure. Zone $\mathrm{B}$ is an alluvial fan which has a relatively low slope, but a thick soil profile and very little vegetation for instance due to rapidly migrating currents on its surface.

Considering the three maps separately, it may be difficult to decide which of the two zones pose the greatest and least risk for catastrophic slope failure. The composite map (Fig. 1f) shows the results of calculations on Table 1. It also depicts both areas as potentially dangerous, but the alluvial fan has somewhat a higher susceptibility to slope failure. It would therefore be prudent 
to situate the geothermal power plant as far as possible from zone B, but without compromising too much on the risk posed by zone A, as suggested in figure 1f. In a real case the same exercise should be done for other types of slope failures such as rock falls or rock slides, if such threats are regarded to be a possibility, as shown in the following example.

\section{RESULTS}

\section{A case study in Hornopirén area, southern Chile}

To test the applicability of composite maps in a real case study, a landslide susceptibility assessment was carried out along the flanks of a fjord in southern Chile. This area lends itself well to this kind of study, because a bivariate statistical susceptibility analysis has already been completed in the same area (SEPÚLVEDA et al. 2011), which can thus be compared directly with the results of the methodology proposed here.

The study area is located at $42^{\circ} \mathrm{S}$ in the Hornopirén district of Chilean Patagonia, where several hot springs occur with significant geothermal energy potential. However, it is also a high-risk area because of the steep slopes along the small fjords (locally called channels) that characterize the region. The main channels, called Hornopirén and Cholgo, respectively, trend NS to NNE, and are connected by the Llancahué Channel (Fig. 2a). The southern limit of the study area is formed by the northern end of the Comau Channel. A smaller EW-trending fjord called Quintumpeu is also included in the study area (Fig. 2a). The Hornopirén, Cholgo and Comau Fjords coincide with the regional trace of the Liquiñe-Ofqui Fault Zone, a major NNE-striking, right-lateral strike-slip structure that accommodates the parallel component of the oblique subduction of the Nazca Plate beneath the South American Plate (CEMBRANO \& HERVÉ 1993; LAVENU \& CEMBRANO 1994; CEMBRANO et al. 2002). The town of Hornopirén is located on an alluvial plain along the northern shore of the Hornopirén Channel. The fjord slopes are steep $\left(>30^{\circ}\right)$ and rise over $1,000 \mathrm{~m}$, whereas the islands in-between the channels (Pelada and Llancahué) have a smoother relief. The geology of the coastline is mainly composed of intrusive rocks of the North Patagonian Batholith and Palaeozoic metamorphic rocks (Levi et al. 1966; NÁQUIRA 2009). North of the town is the Hornopirén Volcano, but it has not registered any recent activity (SEPÚLVEDA et al. 2011). The area shows dozens of landslides of different types, including soil and rock slides, rock falls and debris flows (NÁQUIRA 2009, SEPÚLVEDA et al. 2011; Fig. 2a).

The landslide susceptibility of this area was studied by NÁQUIRA (2009) and SEPÚLVEDA et al. (2011) using a bivariate statistical method. Basically, the method combines intrinsic terrain variables (factor maps) with a landslide inventory (evidence map), which involves various steps. The results of each combination are finally added cell by cell in a grid to obtain a weighted map, which is afterwards reclassified into three levels of susceptibility. The results (Fig. 2a; SEPÚLVEDA et al. 2011) returned high susceptibility values along the western slope of the Hornopirén Channel, most of the eastern slopes of the Cholgo Channel, the northern slope of the Quintumpeu Fjord, the flanks of interior valleys; and locally on the islands. The statistical analyses showed that high susceptibility areas are mainly controlled by the influence of lithology, distance to faults and lineaments, and slope, while fault density and the slope aspect contribute partially, with relatively high weight values (SEPÚLVEDA et al. 2011). 
The same area was analyzed using the composite map method. A hundred and fourteen stations were located on the steep terrain where the bivariate method had been applied (Fig. 2b). Following the suggestions by NÁQUIRA (2009) and SEPÚLVEDA et al. (2011), we chose four parameters to analyze at each station, which are the lithology, slope, distance to faults and lineaments, and the slope aspect. The values were categorized and normalized following the methodology presented above, and added for each station. Parameter maps by NÁQUIRA (2009) were used to categorize the parameters. The distance to faults, lithology and slope aspect were divided into four categories, and classified according to their influence on landslide susceptibility by NÁQUIRA (2009), while the slope values were obtained directly from a digital elevation model. Subsequently, the values were normalized and added for each station. The final sum results varied from 35 to 100 . The values for every station were then interpolated using the Inverse Distance Weighted (IDW) technique in ArcGis. It is important to verify at this stage that the number of stations at the scale of the analysis is sufficient, in order for the interpolation process to return reasonable results.

The results (Fig. 2b) show good agreement with the areas of higher and lower susceptibility indicated by the statistical method (Fig. 2a). In the composite map, the changes in susceptibility are more diffuse due to the interpolation method, in contrast with the bivariate method that computes the value of each cell independently. The presence of the channels between stations precludes in this particular case the use of a denser set of stations and a more refined interpolation, but still the results are quite acceptable. Better results would undoubtedly be obtained if the contours were drawn by hand, where the presence of channels can be taken into account and the geological/engineering knowledge of the researcher would play a role, but we chose to use a simple, unbiased interpolation in this case.

\section{DISCUSSION AND CONCLUSIONS}

Because composite maps are not limited to any particular kind of input parameter, they can be used as a predictive tool in all environments where natural hazards occur, and are not restricted to a single type of hazard such as landslides. In coastal areas, for example, storm surges or tsunamis would be affected by factors such as the offshore bathymetry, onshore topography, and shape of the coastline. This represents an advantage compared to the traditional use of susceptibility or hazard maps constructed by the superposition of thematic maps using predefined, and usually subjective, ratings and weights (e.g. ALEOTTI \& CHOWDHURY 1999; LARA \& SEPÚLVEDA 2010; NADIM et al. 2006, and references therein), which are restricted to the type of phenomenon they were created for. As long as the parameters can be quantified, even if it is on an arbitrary risk scale, they can provide input into composite maps The same method can be used to prepare a multi-hazard map, combining the resulting composite maps of each evaluated hazard. In any case, the assessment must be preceded by a careful selection of the scale of analysis, input parameters and, if necessary, definition of parameter weights. Furthermore, composite maps can be used to delineate the most favourable areas in terms of economic viability, with the possibility to combine such studies with multi-hazard maps. In this way, least risk-highest feasibility areas can be identified and the decision-making process can be optimized in a purely objective, quantitative manner, using as many input factors as may be available. 


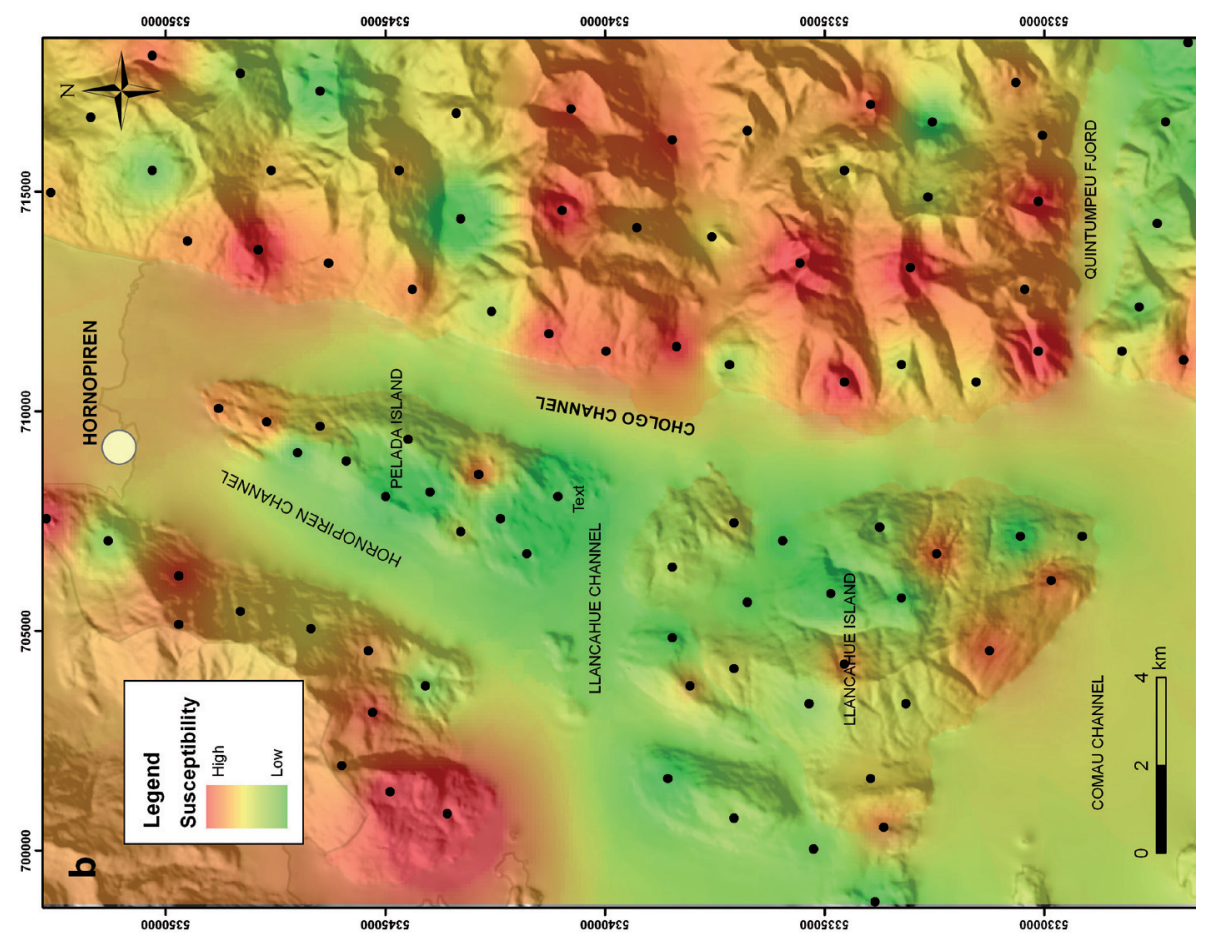

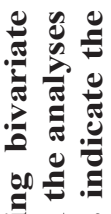

至

巳ั

气ั

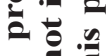

垔

$\sum^{\pi}$

ส

.

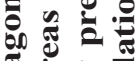

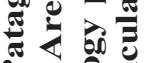

A

$\Xi \underset{\Xi}{ }$

ขึ है

글

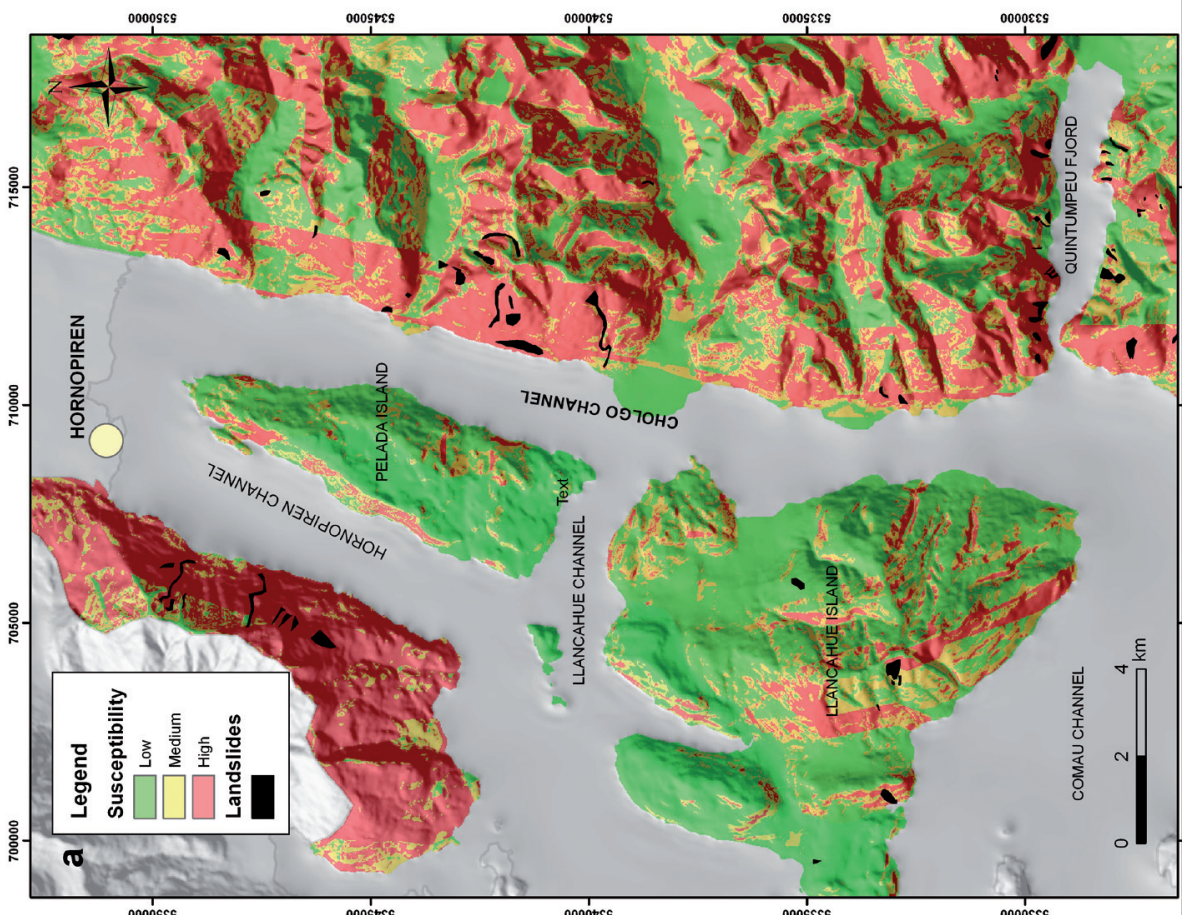

os

을

․ㅡㄹ

류

हु

-

ล้ 气ै है

है

을

产

葛

过

는

䨌

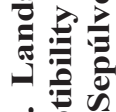

ن 氖苞 
In the hypothetical example, normalization was carried out so that the maximum composite value at any particular station would be 100. Although this could in fact be any number, it is suggested that this should be used as a norm in order to facilitate comparison between different areas. If the parameters are weighted, it should also be carried out in a way that maintains 100 as the standard maximum value. It is hoped that with many case studies, in particular of areas where these types of data were available before catastrophic slope failure or other natural accidents took place, criteria can be developed that would standardize the high-risk cut-off limits on composite maps.

The case study in Patagonia demonstrates that composite maps can be a good approach to assess susceptibility, hazard or even risk, depending on the parameters used. The results, being derived directly from real field data, are not manipulated or even distorted by statistical analysis. Furthermore, the composite map methodology has the advantage that it does not need an inventory of positive cases (of landslides in the example) to run the analyses. However, if parameters are to be weighted for a more precise assessment of susceptibility, a subjective input is introduced, which does not happen in the stochastic methods. In both cases, the selection of the factors to be considered is done by the researcher, therefore this method still needs to be applied by people with expertise in the type of problem to be investigated, and it should not be considered as an "automatic" way of performing susceptibility or hazard analysis. The results may vary a little depending on the chosen interpolation method and the number and position of the stations, thus the selection of these are as important as the parameters to be used. Although the method itself is not dependent on the size of the study area, smaller, more complicated areas obviously require a denser grid of data stations.
In summary, the composite map method, originally applied to paleogeographic reconstructions and mineral exploration, is a viable alternative for susceptibility, hazard, and risk studies. Composite maps can combine any number of different criteria into a single map with equal or weighted input from all the parameters, and also have the potential to standardize prediction and prevention criteria for different areas. They are not restricted to a singular type of natural hazard but can be used for different hazards, as a tool for multi-risk assessment, with the possibility to combine all these factors into a single map. They are thus particularly useful in complex areas where many different factors may play a role in the decision-making process.

\section{ACKNOWLEDGEMENTS}

This paper was written under the auspices of the Andean Geothermal Center of Excellence, CEGA-CONICYT/FONDAP Project 15090013.

\section{REFERENCES}

ALEOTTI, P. \& R. CHOWDHURY, 1999. Landslide hazard assessment: summary review and new perspectives. Bulletin of Engineering Geology and the Environment, 58: 21-44.

CEMBRANO, J. \& F. HERVÉ, 1993. The Liquiñe Ofqui Fault Zone: a major Cenozoic strike slip duplex in the Southern Andes. In: Second ISAG, Oxford (UK), 21-23, 175-178.

CEMBRANO, J., A. LAVENU, P. REYNOLDS, G. ARANCIBIA, G. LÓPEZ \& A. SANHUEZA, 2002. Late Cenozoic transpressional ductile deformation north of the Nazca-South America-Antarctica triple junction. Tectonophysics, 354: 289-31. 
KAMP, U., B.J. GROWLEY, G.A. KHATTAK \& L.A. OWEN, 2008. GISbased landslide susceptibility mapping for the 2005 Kashmir earthquake region. Geomorphology, 101:631-642.

LARA, M. \& S.A. SEPÚLVEDA, 2010. Landslide susceptibility and hazard assessment in San Ramón ravine, Santiago de Chile, from an engineering geological approach. Environmental Earth Sciences, 60: 1227-1243.

LAVENU, A. \& J. CEMBRANO, 1994. Neotectónica de rumbo dextral en la Zona de Falla Liquiñe-Ofqui: geometría, cinemática, y tensor de esfuerzos. In: VII Congreso Geológico Chileno, Actas Volumen I, pp. 8185.

LE ROUX, J.P., 1982. The sedimentology and uranium mineralisation of the Klipbankskraal deposit north of Merweville, C.P. PER-68, Atomic Energy Corporation of S. Afr., Pretoria, 46 pp.

LE ROUX, J.P., 1997. Palaeogeographic reconstruction using composite maps, with case studies from three continents. Palaeogeology, Palaeoclimatology, Palaeoecology, 131:51-63.
LE ROUX, J.P. \& I.C. RUST, 1989 Composite facies maps: a new aid to palaeo-environmental reconstruction. South African Journal of Geology, 92:436-443.

LEVI, B., A. AGUILAR \& R. FUENZALIDA, 1966. Reconocimiento geológico en las provincias de Llanquihue y Chiloé. Instituto de Investigaciones Geológicas, Boletín $N^{\circ} 19$. Santiago

NADIM, F., O. KJEKSTAD, U. DOMAAS, R. RAFAT \& P. PEDUZZI, 2006. Global landslides risk case study. In: Arnold, M. et al. (eds), Natural Disaster Hotspots, Case Studies. The World Bank Disaster Risk Management Series, $\mathrm{N}^{\circ} 6: 21-78$.

NÁQUIRA, M.V., 2009. Susceptibilidad de remociones en masa en las costas de fiordos cercanos a Hornopirén, X Región. Dissertation, Universidad de Chile. Santiago. Inédito.

SEPÚLVEDA, S.A., M.V. NÁQUIRA \& M. ARENAS, 2011. Susceptibility of coastal landslides and related hazards in the Chilean Patagonia: The case of Hornopirén area $\left(42^{\circ} \mathrm{S}\right)$. Investig Geogr. Chile. 43:35-46. 